\title{
Two Limonoids from The Seeds of Chisocheton Macrophyllus and Their Cytotoxic Activity Against Mcf-7 Breast Cancer Cells
}

\author{
Intan Rahmayanti ${ }^{1}$, Nurlelasari ${ }^{1 *}$, Desi Harneti ${ }^{1}$ Rani Maharani ${ }^{1,2}$, Darwati ${ }^{1}$, Yoshihito Shiono ${ }^{3}$, \\ Unang Supratman ${ }^{1,2}$ \\ 'Department of Chemistry, Faculty of Mathematics and Natural Sciences, Universitas Padjadjaran, \\ Jatinangor 45363, Indonesia \\ ${ }^{2}$ Central Laboratory, Universitas Padjadjaran, Jatinangor 45363, Indonesia \\ ${ }^{3}$ Department of Food, Life, and Environmental Science, Faculty of Agriculture, Yamagata University, \\ Tsuruoka, Yamagata 997-8555, Japan.
}

*Corresponding author email: nurlelasari@unpad.ac.id

Received October 07, 2020; Accepted May 30, 2021; Available online July 20, 2021

\begin{abstract}
Limonoids (tetranortriterpenoids) are triterpenoid compounds that lose four terminals in their structural framework. These compounds have a wide variety of structures and interesting activities including anti-inflammatory, anticancer, anti-tumor and anti-malarial properties. The purpose of this study was to find limonoid compounds from the Indonesian Chisocheton plant, and one of which is Chisocheton macrophyllus. The dried and powdered seeds of C. macrophyllus $(4.5 \mathrm{~kg})$ were extracted with methanol and partitioned successively with $n$-hexane, ethyl acetate and $n$-butanol. Evaporation of each extract resulted in the crude extracts of $n$-hexane $(346.6 \mathrm{~g})$, ethyl acetate $(60.8 \mathrm{~g})$ and $\mathrm{n}$-butanol (14.6 g). The $n$-hexane fraction was subjected to a silica gel vacuum-liquid chromatography (VLC) column packed with silica gel 60 using gradient of $n$-hexane, ethyl acetate and methanol (10\% stepwise) to afford thirteen fractions (A-M). Fraction $F(4.4$ g) was subjected to silica gel column chromatography using gradient of $n$-hexane and ethyl acetate $(5 \%$ stepwise). Subfraction F5 (1.2 g) was chromatographed on a column of silica gel eluted with $n$-hexane: $\mathrm{CH}_{2} \mathrm{Cl}_{2}$ : $\mathrm{EtOAc}(2: 7.5: 0.5)$ to give compound $1(19.7 \mathrm{mg})$ and fraction $\mathrm{H}(1.8 \mathrm{~g})$ was subjected to silica gel column chromatography using gradient of $n$ hexane and ethyl acetate ( $5 \%$ stepwise) as eluting solvent to give $2(12.0 \mathrm{mg})$. Chemical structures of 1 and 2 were elucidated by spectroscopic methods and determined as 6a-acetoxyepoxyazadiradione (1) and Dysobinin(2). Dysobinin (2) showed weak cytotoxic activity against MCF-7 breast cancer cells with an IC 50 value of $228.15 \mu \mathrm{M}$
\end{abstract}

Keywords: 6a-acetoxyepoxyazadiradione, C. macrophyllus, dysobinin, limonoid, MCF-7

\section{INTRODUCTION}

Limonoids are a class of tetranortriterpenoids that are formed through the loss of four terminal carbons of side chain of euphane (20-S) or tirucallane $(20-R)$ skeleton that are followed by a cyclization to form a $17 \beta$-furan ring (Tan, \& Luo, 2011; Shi et al., 2020). Limonoids are classified into ten classes based on the differences on $A, B, C, D$, and furan ring of the limonoid skeleton and can be identified by their biosynthetic relationships (Fang, Di, \& Hao, 2011; Tan \& Luo, 2011; Shi et al., 2020). Ten classes of limonoid include protolimonoids, apoeuphol skeleton, $D$-ring seco, B, D-ring seco, A-ring seco, A, B-ring seco, Cring seco, $A, D$-ring seco and $B$-ring seco limonoids.

Limonoids occur mainly in the plant order of Rutales and most of them are found in Meliaceae and Rutaceae families (Li, Peng, \& Zheng, 2016). Limonoids isolated from species of the family of Meliaceae have been of interest due to their diverse structures and their biological activities, including antifeedant, anticancer, antimicrobial, antimalarial, and antiviral properties (Tan, \& Luo, 2011; Wong et al., 2011; Gualdani, Cavalluzzi, Lentini, \& Habtemariam, 2016; Shilpi et al., 2016; Chong et al., 2019; Supratman et al., 2020). Nimbolide is a major limonoid isolated from the leaves of Azadirachta indica A. Juss or known as neem tree. Nimbolide as a neem limonoid is widely used for anti-malaria, antibacterial activity against $S$. aureus and $S$. coagulase, anti-feedant and insecticidal activity (Kumar \& Navaratnam, 2013; Bodduluru, Kasala, Thota, Barua \& Sistla, 2014; Wang et al., 2016; Sophia et al., 2018). Nimbolide was presumed to be a more potent anticancer. Nimbolide shows anticancer activity throughout selective modulation of signaling pathways linked to inflammation, survival, growth, invasion, angiogenesis and metastasis. Nimbolide was reported to induce apoptosis by disruption of Mitochondrial Outer Membrane Potential (MOMP) and inhibits tumor cell proliferation through alterations of cyclins, cdks, PCNA and p53 levels. In addition, nimbolide also reducing the nuclear 
translocation and DNA-binding activity of NF-kB in cancer cells (Kumar \& Navaratnam, 2013; Bodduluru, Kasala, Thota, Barua, \& Sistla, 2014; Wang et al., 2016; Sophia et al., 2018). Beside nimbolide, other limonoids, such azadirachtin, salannin, nimbin and nimbic acid, have been isolated from $A$. indica (Wang et al., 2016). Azadirachtin-A (AzaA) is a prominent limonoid known as strong antifeedant and has been exploited commercially. AzaA is present in seed, leaves and other parts of $A$. indica. Natural pesticide like AzaA is widely used to control the insect. AzaA can keep the insect engaged in defensive while reducing food consumption. In silico studies suggests that AzaA accommodated in the hydrophobic pocket of juvenile hormone esterase and interact with active site residues. AzaA generally targets more than one protein and was presumed to be a potent biopesticide (Dawkar et al., 2019). Other limonoids from Meliaceae family also have potential applications in the food and pharmaceutical industries and have been used as food additives and pesticides (Gualdani, Cavalluzzi, Lentini, \& Habtemariam, 2016; Shi et al., 2020).

Chisocheton plant is a genus from Meliaceae that consists of more than 50 species. The genus is distributed mainly in India, Thailand, Malaysia, Indonesia and becomes the second largest genus of family Meliaceae (Katja et al., 2016; Supriatno et al., 2018). Previous phytochemical studies on Chisocheton have discovered several limonoid compounds, such as malayanines $A$ and $B$, two novel limonoids, that were isolated from the bark of Malaysian C. erythrocarpus Hiern (Chong et al., 2012), chisomicines D and E, two new limonoids, that have been isolated from the bark of Malaysian C. ceramicus (Miq.) (Najmuldeen et al., 2012), chisotrijugin, a trijugin-type limonoid, from the bark of C. cumingianus (Katja et al., 2016), and pentandricine, a new vilacinine-type limonoid, that was isolated from the stembark of $C$. pentandrus, together with ceramicine B, 6-de(acetyloxy)-23oxochisocheton, and 6-de(acetyloxy)-23-oxo-7-Odeacetylchisocheton that have been (Supriatno et al., 2018). Chisocheton genus has also been known as the producers of limonoid compounds with interesting biological activities, for example, ceramicine $G$ and I from C. ceramicus, which have cytotoxic activity against MCF-7 breast cancer cells (Wong et al., 2011) and erythrocarpine $\mathrm{E}$ from $\mathrm{C}$. erythrocarpus, which has anticancer properties against HSC-4 human oral cancer cells (Nagoor et al., 2011).

In order to investigate cytotoxic limonoids from Indonesian Chisocheton plants (Katja et al., 2016; Nurlelasari et al., 2017), we continue to carry out a phytochemical investigation on Chisocheton macrophyllus seeds. C. macrophyllus species are distributed in Nicobar Islands, peninsular Thailand, Peninsular Malaysia, Singapore, Sumatra, Anambas Islands, Java and also Borneo. C. macrophyllus is a higher plant with the tree up to $35 \mathrm{~m}$ tall. The oil isolated from C. macrophyllus seed has been used for lighting in Indonesia. The wood of C. macrophyllus are used as timber because it is not durable and splits easily (Vossen, \& Umali, 2002; Nurlelasari et al., 2017). Previous investigation on limonoids from $C$. macrophyllus seeds has showed that the plant resulted in bioactive limonoids including dysobinol, 7 $\alpha$ hydroxyneotricilenone, dysobinin and nimonol with cytotoxic activity against P-388 murine leukemia cells (Nurlelasari et al., 2017). In this paper, we describe the isolation, structure elucidation and cytotoxic properties against MCF-7 breast cancer cells of $6 \alpha-$ acetoxyepoxyazadiradione (1) and dysobinin (2), isolated from C. macrophyllus seeds.

\section{EXPERIMENTAL SECTION \\ Material and instrumentation}

Seeds of C. macrophyllus were collected from Bogor Botanical Garden, Bogor, West Java Province, Indonesia with voucher specimen (No. Bo-1295453).

IR spectra and mass spectra were recorded on an One PerkinElmer spectrum-100 FT-IR in $\mathrm{KBr}$ and Waters Xevo QTOF MS respectively. NMR spectra were obtained with JEOL JNM-ECZ500R/S1 at $500 \mathrm{MHz}$ for ${ }^{1} \mathrm{H}$ and $125 \mathrm{MHz}$ for ${ }^{13} \mathrm{C}$. Chemical shifts are given on a $\delta$ (ppm) scale with tetramethylsilane (TMS) as an internal standard. Chromatographic separations were carried out on the silica gel 60 (70-230 and 230-400 mesh, Merck). TLC analysis was carried out on 60 $\mathrm{GF}_{254}$ (Merck, $0.25 \mathrm{~mm}$ ) using various solvent systems, and detection by irradiating under ultraviolet-visible light Vilber Lourmat ( $\lambda 254 \mathrm{~nm}$ dan $\lambda 365 \mathrm{~nm}$ ) followed by heating of silica gel plates, sprayed with $10 \% \mathrm{H}_{2} \mathrm{SO}_{4}$ in ethanol and Ehrlich's reagent ( $p$ dimethylaminobenzaldehyde).

\section{Extraction and isolation}

The dried and powdered seeds of C. macrophyllus $(4.5 \mathrm{~kg})$ was extracted with methanol at room temperature for $3 \times 4 \mathrm{~L} \times 24$ hours. After the solvent removal under vacuum, a total $560 \mathrm{~g}$ of methanol extract was obtained and partitioned with $n$-hexane, ethyl acetate and $n$-butanol. Evaporation on each extract resulted the crude extracts of $n$-hexane (346.6 $\mathrm{g})$, ethyl acetate $(60.8 \mathrm{~g})$ and $n$-butanol (14.6 g).

The $n$-hexane soluble fraction was subjected to a silica gel vacuum-liquid chromatography (VLC) column packed with silica gel 60 using gradient of $n$ hexane, ethyl acetate and methanol (10\% stepwise) to afford thirteen fractions $(A-M)$. Fraction $F(4.4 \mathrm{~g})$ was subjected to silica gel column chromatography using gradient of $n$-hexane and ethyl acetate (5\% stepwise) as eluting solvent to afford twelve subfractions ( $F 1$ F12). Subfraction F5 (1.2 g) was chromatographed on a column of silica gel eluted with $n$-hexane: $\mathrm{CH}_{2} \mathrm{Cl}_{2}$ : EtOAc (2:7.5:0.5) to give compound 1 (19.7 $\mathrm{mg})$. Fraction $\mathrm{H}(1.8 \mathrm{~g})$ was subjected to silica gel column chromatography using gradient of $n$-hexane and ethyl acetate (5\% stepwise) as eluting solvent to give 2 (12.0 $\mathrm{mg})$. 


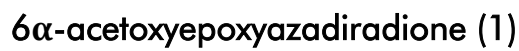

Colorless crystals $220-221^{\circ} \mathrm{C} ; \mathrm{IR}(\mathrm{KBr}) v_{\max } 2922$, $1741,1668,1503,1365$ and $1244 \mathrm{~cm}^{-1} ;{ }^{1} \mathrm{H}-\mathrm{NMR}$ $\left(\mathrm{CDCl}_{3}, 500 \mathrm{MHz}\right)$ and ${ }^{13} \mathrm{C}-\mathrm{NMR}\left(\mathrm{CDCl}_{3}, 125 \mathrm{MHz}\right)$ see Table 1; HR-TOFMS m/z 547.2302 $[\mathrm{M}+\mathrm{Na}]^{+}$, (calcd. $\mathrm{C}_{30} \mathrm{H}_{36} \mathrm{O}_{8} \mathrm{Na} \mathrm{m} / z$ 547.2308).

\section{Dysobinin (2)}

Colorless crystals $196-197^{\circ} \mathrm{C} ; \mathrm{IR}(\mathrm{KBr}) v_{\max } 2919$, $1740,1667,1502,1382 ; 1362,1234 \mathrm{~cm}^{-1} ;{ }^{1} \mathrm{H}-\mathrm{NMR}$ $\left(\mathrm{CDCl}_{3}, 500 \mathrm{MHz}\right)$ and ${ }^{13} \mathrm{C}-\mathrm{NMR}\left(\mathrm{CDCl}_{3}, 125 \mathrm{MHz}\right)$ see Table 1; HR-TOFMS m/z $495.2741[\mathrm{M}+\mathrm{H}]^{+}$, (calcd. $\mathrm{C}_{30} \mathrm{H}_{39} \mathrm{O}_{6} \mathrm{~m} / \mathrm{z}$ 495.2747).

\section{Bioassays for cytotoxic activity}

The cytotoxicity assay was conducted according to the method previously described by Examinati, Wulandari, Harneti, \& Poniah (2018) and Supriatno et al., (2018). MCF-7 cells plated in 96 multiwell culture plates at a density of $1.7 \times 10^{4}$ cells/well. After twentyfour hours, medium was discarded and fresh medium containing sample with different concentrations 7.81 , $15.63,31.25,62.50,125.00,250.00,500.00$, $1000.00 \mu \mathrm{g} / \mathrm{mL}$ and control was added. After incubation with sample for $24 \mathrm{~h}$, prestoBlue ${ }^{\circledR}$ reagent (resazurin dye) was added. The PrestoBlue ${ }^{\circledR}$ assay results were read using multimode reader at $570 \mathrm{~nm}$. The $I C_{50}$ values were determined by linier regression method using Microsoft Excel software. The IC $\mathrm{C}_{50}$ value corresponds to the concentration of compounds that decreases $50 \%$ number of viable cells and the absorbance in control corresponds to $100 \%$ viability.

\section{RESULTS AND DISCUSSION}

The $n$-hexane extract from the seeds of $C$. macrophyllus was subjected to a silica gel vacuumliquid chromatography (VLC) column packed with silica gel 60 by gradient elution. The VLC fractions were repeatedly subjected to normal phase column chromatography on silica gel to yield compounds 1 and 2 (Figure 1).

Compound 1 was isolated as a colorless crystals with $220-221^{\circ} \mathrm{C}$. The HR-TOFMS showed the presence of $[\mathrm{M}+\mathrm{Na}]^{+}$peak at $\mathrm{m} / \mathrm{z} 547.2302$ (calcd $\mathrm{m} / \mathrm{z}$ for $\mathrm{C}_{30} \mathrm{H}_{36} \mathrm{O}_{8} \mathrm{Na}$, 547.2308), indicating the molecular formula of $\mathrm{C}_{30} \mathrm{H}_{36} \mathrm{O}_{8}$. UV spectrum in $\mathrm{MeOH}$ showed $\lambda_{\max } 220 \mathrm{~nm}$ and IR absorptions suggested the presence of aliphatic $\left(v_{\max } 2922 \mathrm{~cm}^{-1}\right)$, carbonyl ester $\left(v_{\max } 1741 \mathrm{~cm}^{-1}\right), \alpha, \beta$-unsaturated carbonyl $\left(v_{\max } 1668\right.$ $\left.\mathrm{cm}^{-1}\right)$, olefinic $\left(v_{\max } 1503 \mathrm{~cm}^{-1}\right)$, gem dimethyl $\left(v_{\max }\right.$ $\left.1365 \mathrm{~cm}^{-1}\right)$, and ether groups $\left(v_{\max } 1244 \mathrm{~cm}^{-1}\right)$. The 'H-NMR spectrum showed five tertiary methyls at $\delta_{\mathrm{H}}$ $1.01(3 \mathrm{H}, \mathrm{s}, \mathrm{Me}-29), 1.14(3 \mathrm{H}, \mathrm{s}, \mathrm{Me}-18), 1.19(3 \mathrm{H}$, $\mathrm{s}, \mathrm{Me}-30), 1.23(3 \mathrm{H}, \mathrm{s}, \mathrm{Me}-19)$ and $1.30(3 \mathrm{H}, \mathrm{s}, \mathrm{Me}-$ 28). Two acetoxyl groups $\delta_{\mathrm{H}} 2.06\left(3 \mathrm{H}, \mathrm{s}, \mathrm{H}-\mathrm{l}^{\prime}\right)$ and $2.00(3 \mathrm{H}, \mathrm{s}, \mathrm{H}-1 ")$. Three oxygenated protons at $\delta_{\mathrm{H}}$ $5.34(1 \mathrm{H}, \mathrm{dd}, J=2.6,12.5 \mathrm{~Hz}, \mathrm{H}-6), 5.01(1 \mathrm{H}, \mathrm{d}, J$ $=2.6 \mathrm{~Hz}, \mathrm{H}-7)$ and $3.40(1 \mathrm{H}, \mathrm{s}, \mathrm{H}-15)$, a $\beta$-furan moiety at $\delta_{\mathrm{H}} 6.21(1 \mathrm{H}, \mathrm{d}, J=1.45 \mathrm{~Hz}, \mathrm{H}-22), 7.38$ $(1 \mathrm{H}, \mathrm{d}, J=1.45 \mathrm{~Hz}, \mathrm{H}-23)$ and $7.54(1 \mathrm{H}, \mathrm{s}, \mathrm{H}-21)$ and two olefinic protons at $\delta_{H} 5.93(1 \mathrm{H}, \mathrm{d}, J=10.5$ $\mathrm{Hz}, \mathrm{H}-2)$, and $7.11(1 \mathrm{H}, \mathrm{d}, J=10.5 \mathrm{~Hz}, \mathrm{H}-1)$. The ${ }^{13} \mathrm{C}$-NMR and DEPT spectra showed thirty carbons consisting of an $\alpha, \beta$-unsaturated carbonyl at $\delta_{C} 204.5$ (C-3), carbonyl ketone at $\delta_{C} 208.1$ (C-16), two acetoxyl groups at $\delta_{C} 21.2\left(C^{2}-1^{\prime}\right), 170.0\left(C-2^{\prime}\right), 21.3$ (C-1") and 170.1 (C-2"), five methyls at $\delta_{C} 19.1$ (Me28), 20.3 (Me-18), 21.7 (Me-30), 24.8 (Me-29) and 31.7 (Me-19). The spectra also showed two methylene carbons at $\delta_{c} 16.2(C-11)$ and $28.7(C-12)$, three $s p^{3}$ methine carbons at $\delta_{C} 38.5(C-9), 48.5$ (C-5) and 50.9 $(\mathrm{C}-17)$, three $s p^{2}$ methine carbons at $\delta_{C} 111.0$ (C-22), $126.6(\mathrm{C}-2)$ and $156.9(\mathrm{C}-1)$, three oxygenated $\mathrm{sp}^{3}$ methine carbons at $\delta_{\mathrm{C}} 57.1$ (C-15), 69.9 (C-6) and 73.1 (C-7), two oxygenated $s p^{2}$ methine carbons at $\delta_{C}$ 141.7 (C-21) and 142.6 (C-23), four $s p^{3}$ quaternary carbons at $\delta_{C} 40.5$ (C-10), 42.5 (C-8), 43.3 (C-4), and 45.3 (C-13), an oxygenated $s p^{3}$ quaternary carbons at $\delta_{C} 72.4(C-14)$, and one $s p^{2}$ quaternary carbons at $\delta_{C}$ 116.5 (C-20). These functionalities accounted for seven out of the total thirteen degrees of unsaturation $\left(\mathrm{C}_{30} \mathrm{H}_{36} \mathrm{O}_{8}\right)$, while the remaining six degrees of unsaturation corresponded to the pentacyclic limonoid structure (Wong et al., 2011; Najmuldeen et al., 2012; Nurlelasari et al., 2017; Supriatno et al., 2018) with an additional cyclic. The NMR spectra data of 1 were resembled to those of previously reported dysobinin (Nurlelasari et al., 2017), except for the absence of olefinic signals at C-14/C-15 and instead the appearance of oxygenated signals $\left[\delta_{\mathrm{H}} 3.40(1 \mathrm{H}\right.$, s), $\delta_{c} 57.1$ and $\left.\delta_{c} 72.4\right]$ and carbonyl at $\delta_{c} 208.1$, thus suggesting the appearance epoxide between C-14 and $\mathrm{C}-15$ and carbonyl at C-16 in structure 1. Position of these carbonyl at C-16 and epoxide between C-14 and $\mathrm{C}-15$ was determined through the ${ }^{1} \mathrm{H}-{ }^{1} \mathrm{H}$ COSY and $\mathrm{HMBC}$ experiments (Figure 2). ${ }^{1} \mathrm{H}-{ }^{1} \mathrm{H}$ COSY spectrum of 1 in $\mathrm{CDCl}_{3}$ (Figure 2), showed correlation in $\mathrm{H}_{1}-\mathrm{H}_{2}, \mathrm{H}_{5}-\mathrm{H}_{6}-\mathrm{H}_{7}, \mathrm{H}_{11}-\mathrm{H}_{12}$ and $\mathrm{H}_{22}-\mathrm{H}_{23}$. Four partial structures a (from C-1 to C-2), b (from C-5 to C-7), c (C-11 to C-12), and d (from C-22 to C-23) were deduced from this ${ }^{1} \mathrm{H}-{ }^{1} \mathrm{H}$ COSY data and supporting the presence of a havanensin-type of limonoid structure in 1. Data from HMBC spectrum showed ${ }^{3} \mathrm{~J}$ correlations between $s p^{2}$ methine proton signal $\delta_{\mathrm{H}}$ $7.11(\mathrm{H}-1)$ and $\delta_{\mathrm{C}} 48.5(\mathrm{C}-5)$ and carbonyl at $\delta_{\mathrm{C}}$ $204.5(\mathrm{C}-3)$ and a correlation between $\delta_{H} 5.93(\mathrm{H}-2)$ and $\delta_{C} 40.5(\mathrm{C}-10)$. Furthermore, olefinic protons at $\delta_{\mathrm{H}} 7.11(1 \mathrm{H}, \mathrm{d}, J=10.5 \mathrm{~Hz}, \mathrm{H}-1)$ and $\delta_{\mathrm{H}} 5.93(1 \mathrm{H}, \mathrm{d}$, $J=10.5 \mathrm{~Hz}, \mathrm{H}-2)$ are coupled each other indicating that an $\alpha, \beta$-unsaturated carbonyl was located at C-1, $\mathrm{C}-2$ and $\mathrm{C}-3$. Correlations from oxygenated $s \mathrm{p}^{3}$ methine protons at $\delta_{\mathrm{H}} 5.34(\mathrm{H}-6)$ to $\delta_{\mathrm{C}} 48.5(\mathrm{C}-5), \delta_{\mathrm{C}}$ $73.1(\mathrm{C}-7)$ and $\delta_{\mathrm{C}} 170.0\left(\mathrm{C}-2^{\prime}\right), \delta_{\mathrm{H}} 5.01(\mathrm{H}-7)$ to $\delta_{\mathrm{C}}$ $48.5(\mathrm{C}-5), \delta_{\mathrm{C}} 69.9(\mathrm{C}-6), \delta_{\mathrm{C}} 42.5(\mathrm{C}-8), \delta_{\mathrm{C}} 38.5$ (C9) and $\delta_{C} 170.1\left(\mathrm{C}-2{ }^{\prime \prime}\right), \delta_{\mathrm{H}} 2.06\left(\mathrm{H}-1^{\prime}\right)$ to $\delta_{\mathrm{C}} 170.0$ (C$\left.2^{\prime}\right)$ and $\delta_{\mathrm{H}} 2.00(\mathrm{H}-1 ")$ to $\delta_{\mathrm{C}} 170.1(\mathrm{C}-2 ")$ indicating that acetyl group was attached at C-6 and C-7. 
Correlations from oxygenated $\mathrm{sp}^{3}$ methine protons at $\delta_{\mathrm{H}} 3.40(\mathrm{H}-15)$ to $\delta_{\mathrm{C}} 208.1$ (C-16) and $\delta_{\mathrm{C}} 50.9$ (C-17) and correlations from $\delta_{\mathrm{H}} 3.86(\mathrm{H}-17)$ to $\delta_{\mathrm{C}} 28.7(\mathrm{C}$ $12), \delta_{C} 45.3$ (C-13), $\delta_{C} 208.1$ (C-16), $\delta_{C} 116.5$ (C$20), \delta_{C} 141.7(C-21)$ and $\delta_{C} 111.0$ (C-22) were used to assign position of an epoxide between C-14 and C15, a carbonyl located on C-16 and a furan ring attached at C-17. Chemical structure of 1 was presumed to be the same as $6 \alpha$ acetoxyepoxyazadiradione due to the high similarity of the NMR chemical shifts that was previously reported (Table 1.) (Pereira et al., 2014). The indicating the relative stereochemistry of epoxide between C-14/C15 of 1 are $\beta$-oriented and acetyl group at C-6 and C-7 is $\alpha$-oriented. Therefore, compound 1 was identified as a $6 \alpha$-acetoxyepoxyazadiradione and showed in this plant for the first time.

Compound (2) was isolated as a colorless crystals with $196-197^{\circ} \mathrm{C}$. The $[\mathrm{M}+\mathrm{H}]^{+}$peak at $\mathrm{m} / \mathrm{z} 495.2741$ (calcd for $\mathrm{C}_{30} \mathrm{H}_{39} \mathrm{O}_{6}, 495.2747$ ), HR-TOFMS indicated the molecular formula $\mathrm{C}_{30} \mathrm{H}_{38} \mathrm{O}_{6}$, and $\mathrm{NMR}$ data (Table 2), thus requiring twelve degrees of unsaturation. IR absorptions suggested the presence of aliphatic $\left(v_{\max } 2919 \mathrm{~cm}^{-1}\right)$, carbonyl ester $\left(v_{\max } 1740\right.$ $\left.\mathrm{cm}^{-1}\right), \alpha, \beta$-unsaturated carbonyl $\left(v_{\max } 1667 \mathrm{~cm}^{-1}\right)$, olefinic $\left(v_{\max } 1502 \mathrm{~cm}^{-1}\right)$, gem dimethyl $\left(v_{\max } 1382\right.$; $\left.1362 \mathrm{~cm}^{-1}\right)$, and ether groups $\left(v_{\max } 1234 \mathrm{~cm}^{-1}\right)$. The ' $\mathrm{H}-\mathrm{NMR}$ spectrum showed five tertiary methyls at $\delta_{\mathrm{H}}$ $0.78(3 \mathrm{H}, \mathrm{s}, \mathrm{Me}-28), 1.17(3 \mathrm{H}, \mathrm{s}, \mathrm{Me}-19), 1.17(3 \mathrm{H}$, s, Me-30), $1.23(3 \mathrm{H}, \mathrm{s}, \mathrm{Me}-29)$ and $1.31(3 \mathrm{H}, \mathrm{s}, \mathrm{Me}-$ 18). Two acetoxyl groups $\delta_{H} 1.99\left(3 \mathrm{H}, \mathrm{s}, \mathrm{H}-1{ }^{\prime}\right)$ and $2.03(3 \mathrm{H}, \mathrm{s}, \mathrm{H}-1 ")$. Two oxygenated protons at $\delta_{\mathrm{H}} 5.36$ $(1 \mathrm{H}, \mathrm{dd}, \mathrm{J}=4.5,3.5 \mathrm{~Hz}, \mathrm{H}-6)$ and $5.41(1 \mathrm{H}, \mathrm{d}, \mathrm{J}=$ $2.6 \mathrm{~Hz}, \mathrm{H}-7)$, a 6 -furan moiety at $\delta_{\mathrm{H}} 6.25(1 \mathrm{H}, \mathrm{d}, \mathrm{J}=$ $1.45 \mathrm{~Hz}, \mathrm{H}-22), 7.36(1 \mathrm{H}, \mathrm{d}, \mathrm{J}=1.45 \mathrm{~Hz}, \mathrm{H}-23)$ and $7.22(1 \mathrm{H}, \mathrm{s}, \mathrm{H}-21)$ and two olefinic protons at $\delta_{\mathrm{H}} 5.90$ $(1 \mathrm{H}, \mathrm{d}, \mathrm{J}=10.5 \mathrm{~Hz}, \mathrm{H}-2)$, and $7.12(1 \mathrm{H}, \mathrm{d}, J=10.5$ $\mathrm{Hz}, \mathrm{H}-1)$. The ${ }^{13} \mathrm{C}$ NMR and DEPT spectra showed thirty carbons consisting of an $\alpha, \beta$-unsaturated carbonyl at $\delta_{C} 204.8$ (C-3), two acetoxyl groups at $\delta_{C} 21.0$ (C-1'),
170.2 (C-2'), 21.4 (C-1") and 170.3 (C-2"), five methyls at $\delta_{C} 20.5$ (Me-28), 20.8 (Me-29), 22.7 (Me30), 26.8 (Me-18) and 31.7 (Me-19). The spectra also showed three methylene carbons at $\delta_{C} 16.5$ (C-11), 34.4 (C-12) and 32.7 (C-16), three $\mathrm{sp}^{3}$ methine carbons at $\delta_{C} 37.3$ (C-9), 47.9 (C-5) and 51.6 (C-17), four $\mathrm{sp}^{2}$ methine carbons at $\delta_{\mathrm{C}} 111.0$ (C-22), 119.8 (C-15), 126.2 (C-2) and 157.4 (C-1), two oxygenated $\mathrm{sp}^{3}$ methine carbons at $\delta_{\mathrm{C}} 70.0$ (C-6) and 74.6 (C-7), two oxygenated $\mathrm{sp}^{2}$ methine carbons at $\delta_{C} 139.8$ (C21 ) and 142.7 (C-23), four $s p^{3}$ quaternary carbons at $\delta_{C} 40.8$ (C-10), 43.0 (C-8), 45.0 (C-4), and 47.1 (C13) and two $s p^{2}$ quaternary carbons at $\delta_{C} 124.5$ (C20) and 158.2 (C-14). These functionalities accounted for seven out of the total twelve degrees of unsaturation, while the remaining five degrees of unsaturation corresponded to the pentacyclic limonoid structure (Wong et al., 2011; Najmuldeen et al., 2012; Nurlelasari et al., 2017; Supriatno et al., 2018). Structure of 2 was presumed to be the same as dysobinin because of the high similarity of the NMR chemical shifts of the backbone skeleton (Nurlelasari et al., 2017). Therefore, the structure of $\mathbf{2}$ was elucidated as havanensin-type of limonoid and namely as dysobinin.

Compounds 1 and 2 were evaluated for their cytotoxic activity against MCF-7 breast cancer cell and cisplatin as a positive control according to a method previously described (Examinati, Wulandari, Harneti, \& Poniah, 2018; Supriatno et al., 2018). $6 \alpha$ Acetoxyepoxyazadiradione (1) was found to be inactive and dysobinin (2) demonstrated weak cytotoxic activity against MCF-7 breast cancer cell line with $\mathrm{IC}_{50}$ values of $228.15 \mu \mathrm{M}$ whereas cisplatin as the positive control has $\mathrm{IC}_{50}$ value of $11.42 \mu \mathrm{M}$. The bioassay result, suggested that the carbonyl at C-16 and epoxide at C-14/C-15 in $6 \alpha$ acetoxyepoxyazadiradione (1) decreased the cytotoxic activity.<smiles>CC(=O)O[C@@H]1[C@@H](OC(C)=O)[C@]2(C)C3=CC[C@@H](c4ccoc4)[C@]3(C)CCC2[C@]2(C)C=CC(=O)C(C)(C)[C@H]12</smiles>

Figure 1. Chemical Structures of Compound 1 and 2. 


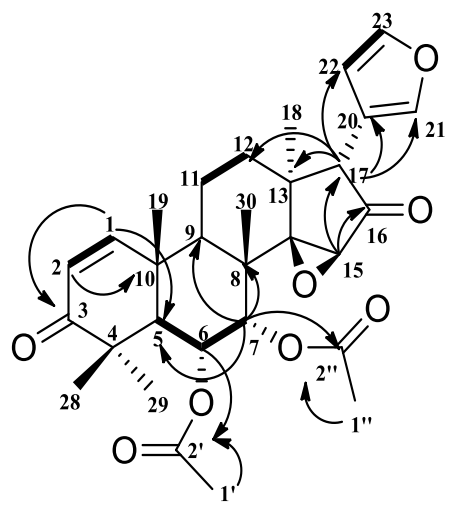

\section{$-{ }^{1} \mathrm{H}-{ }^{1} \mathrm{H}$ COSY}

$\frown \mathrm{HMBC}$

Figure 2. Selected ${ }^{1} \mathrm{H}-{ }^{1} \mathrm{H}$ COSY and $\mathrm{HMBC}$ Correlations for 1.

Tabel 1. NMR data for compounds 1 dan 6a-acetoxyepoxyazadiradione (Pereira et al., 2014) (CDCl 300 $\mathrm{MHz}$ for ${ }^{1} \mathrm{H}$ and 125 for ${ }^{13} \mathrm{C}$ )

\begin{tabular}{|c|c|c|c|c|}
\hline \multirow[b]{2}{*}{ Posisi C } & \multicolumn{2}{|l|}{ *F5 } & \multicolumn{2}{|c|}{${ }^{* *} 6 \alpha$-acetoxyepoxyazadiradione } \\
\hline & $\begin{array}{c}{ }^{1} \mathrm{H}-\mathrm{NMR} \\
\delta_{\mathrm{H}} \mathrm{ppm}(\Sigma \mathrm{H} ; \text { mult; } J=\mathrm{Hz})\end{array}$ & $\begin{array}{l}{ }^{13} \mathrm{C}-\mathrm{NMR} \\
\delta_{\mathrm{c}} \mathrm{ppm}\end{array}$ & $\begin{array}{c}\text { 'H }-\mathrm{NMR} \\
\delta_{\mathrm{H}} \mathrm{ppm}(\Sigma \mathrm{H} ; \text { mult; } J=\mathrm{Hz})\end{array}$ & $\begin{array}{l}{ }^{13} \mathrm{C}-\mathrm{NMR} \\
\delta_{\mathrm{C}} \mathrm{ppm}\end{array}$ \\
\hline 1 & $7.11(1 \mathrm{H} ; \mathrm{d} ; 10.5)$ & 156.9 & $7.16(1 \mathrm{H} ; \mathrm{d} ; 10.1)$ & 156.7 \\
\hline 2 & $5.93(1 \mathrm{H} ; \mathrm{d} ; 10.5)$ & 126.6 & $5.99(1 \mathrm{H} ; \mathrm{d} ; 10.1)$ & 126.5 \\
\hline 3 & - & 204.5 & - & 204.4 \\
\hline 4 & - & 43.3 & - & 45.2 \\
\hline 5 & $2.48(1 \mathrm{H} ; \mathrm{d} ; 12.5)$ & 48.5 & $2.54(1 \mathrm{H} ; \mathrm{d} ; 12.5)$ & 48.5 \\
\hline 6 & $5.34(1 \mathrm{H} ; \mathrm{dd} ; 2.6 ; 12.5)$ & 69.9 & $5.40(1 \mathrm{H} ; \mathrm{dd} ; 2,6 ; 12.5)$ & 69.8 \\
\hline 7 & $5.01(1 \mathrm{H} ; \mathrm{d} ; 2.6)$ & 73.1 & $5.06(1 \mathrm{H} ; \mathrm{d} ; 2.6)$ & 73.0 \\
\hline 8 & - & 42.5 & - & 43.2 \\
\hline 9 & $2.64(1 \mathrm{H} ; \mathrm{dd} ; 2.6 ; 12.5)$ & 38.5 & $2.71(1 \mathrm{H} ; \mathrm{dd} ; 4.0 ; 12.5)$ & 38.4 \\
\hline 10 & & 40.5 & - & 40.5 \\
\hline 11 & $1.90(2 \mathrm{H} ; \mathrm{m})$ & 16.2 & $2.19(1 \mathrm{H} ; \mathrm{m}) ; 1.88(1 \mathrm{H} ; \mathrm{m})$ & 16.1 \\
\hline 12 & $2.65(2 \mathrm{H} ; \mathrm{dd} ; 4.0 ; 12.5)$ & 28.7 & $2.03(1 \mathrm{H} ; \mathrm{m}) ; 1.95(1 \mathrm{H} ; \mathrm{m})$ & 28.6 \\
\hline 13 & & 45.3 & - & 42.5 \\
\hline 14 & - & 72.4 & - & 72.2 \\
\hline 15 & $3.40(1 \mathrm{H} ; \mathrm{s})$ & 57.1 & $3.46(1 \mathrm{H} ; \mathrm{s})$ & 57.0 \\
\hline 16 & & 208.1 & 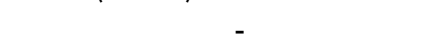 & 207.9 \\
\hline 17 & $3.86(1 \mathrm{H} ; \mathrm{s})$ & 50.9 & $3.92(1 \mathrm{H} ; \mathrm{s})$ & 50.8 \\
\hline 18 & $1.14(3 \mathrm{H} ; \mathrm{s})$ & 20.3 & $1.07(3 \mathrm{H} ; \mathrm{s})$ & 24.7 \\
\hline 19 & $1.23(3 \mathrm{H} ; \mathrm{s})$ & 31.7 & $1.24(3 \mathrm{H} ; \mathrm{s})$ & 21.5 \\
\hline 20 & - & 116.5 & - & 116.4 \\
\hline 21 & $7.54(1 \mathrm{H} ; \mathrm{s})$ & 141.7 & $7.43(1 \mathrm{H} ; \mathrm{t} ; 1.6)$ & 142.5 \\
\hline 22 & $6.21(1 \mathrm{H} ; \mathrm{d} ; 1.45)$ & 111.0 & $6.26(1 \mathrm{H} ; \mathrm{d} ; 1.6)$ & 110.9 \\
\hline 23 & $7.38(1 \mathrm{H} ; \mathrm{d} ; 1.45)$ & 142.6 & $7.41(1 \mathrm{H} ; \mathrm{s})$ & 141.6 \\
\hline 28 & $1.30(3 \mathrm{H} ; \mathrm{s})$ & 19.1 & $1.29(3 \mathrm{H} ; \mathrm{s})$ & 31.6 \\
\hline 29 & $1.01(3 \mathrm{H} ; \mathrm{s})$ & 24.8 & $1.20(3 \mathrm{H} ; \mathrm{s})$ & 20.2 \\
\hline 30 & $1.19(3 \mathrm{H} ; \mathrm{s})$ & 21.7 & $1.36(3 \mathrm{H} ; \mathrm{s})$ & 19.0 \\
\hline $1^{\prime}$ & $2.06(3 \mathrm{H} ; \mathrm{s})$ & 21.2 & $2.11(3 \mathrm{H} ; \mathrm{s})$ & 21.2 \\
\hline $2^{\prime}$ & & 170.0 & - & 169.9 \\
\hline $1^{\prime \prime}$ & $2.00(3 \mathrm{H} ; \mathrm{s})$ & 21.3 & $2.05(3 \mathrm{H} ; \mathrm{s})$ & 21.1 \\
\hline $2^{\prime \prime}$ & - & 170.1 & - & 169.8 \\
\hline
\end{tabular}

* $\left(\mathrm{CDCl}_{3} ;{ }^{1} \mathrm{H}-\mathrm{NMR} 500 \mathrm{MHz} ;{ }^{13} \mathrm{C}-\mathrm{NMR} 125 \mathrm{MHz}\right)$

${ }^{* *}\left(\mathrm{CDCl}_{3} ;{ }^{1} \mathrm{H}-\mathrm{NMR} 500 \mathrm{MHz} ;{ }^{13} \mathrm{C}-\mathrm{NMR} 125 \mathrm{MHz}\right)$ 
Tabel 2. NMR data for compounds 2 and dysobinin (Nurlelasari et al., 2016).

\begin{tabular}{|c|c|c|c|c|}
\hline \multirow{3}{*}{$\begin{array}{c}\text { Posisi } \\
\text { C }\end{array}$} & \multicolumn{2}{|l|}{${ }^{*} \mathrm{H}$} & \multicolumn{2}{|l|}{ **Dysobinin } \\
\hline & ${ }^{1} \mathrm{H}-\mathrm{NMR}$ & ${ }^{13} \mathrm{C}-\mathrm{NMR}$ & ${ }^{1} \mathrm{H}-\mathrm{NMR}$ & ${ }^{13} \mathrm{C}-\mathrm{NMR}$ \\
\hline & $\delta_{\mathrm{H}} \mathrm{ppm}(\Sigma \mathrm{H} ;$ mult; $J=\mathrm{Hz})$ & $\delta_{c} \mathrm{ppm}$ & $\delta_{\mathrm{H}} \mathrm{ppm}(\Sigma \mathrm{H} ;$ mult; $J=\mathrm{Hz})$ & $\delta_{c} \mathrm{ppm}$ \\
\hline 1 & $7.12(1 \mathrm{H} ; \mathrm{d} ; 10.5)$ & 157.4 & $7.3(1 \mathrm{H} ; \mathrm{d} ; 10.3)$ & 158.2 \\
\hline 2 & $5.90(1 \mathrm{H} ; \mathrm{d} ; 10.5)$ & 126.2 & $5.84(1 \mathrm{H} ; \mathrm{d} ; 10.3)$ & 126.6 \\
\hline 3 & - & 204.8 & & 204.1 \\
\hline 4 & - & 45.0 & - & 45.6 \\
\hline 5 & $2.48(1 \mathrm{H} ; \mathrm{d} ; 14.0)$ & 47.9 & $2.5(1 \mathrm{H} ; \mathrm{m})$ & 48.9 \\
\hline 6 & $5.36(1 \mathrm{H} ; \mathrm{dd} ; 4.5 ; 3.5)$ & 70.0 & $5.40(1 \mathrm{H} ; \mathrm{m})$ & 70.0 \\
\hline 7 & $5.41(1 \mathrm{H} ; \mathrm{d} ; 2.6)$ & 74.6 & $5.40(1 \mathrm{H} ; \mathrm{m})$ & 75.1 \\
\hline 8 & - & 43.0 & - & 43.9 \\
\hline 9 & $2.41(1 \mathrm{H} ; \mathrm{m})$ & 37.3 & $1.28(1 \mathrm{H} ; \mathrm{m})$ & 38.3 \\
\hline 10 & - & 40.8 & - & 41.6 \\
\hline 11 & $1.62(2 \mathrm{H} ; \mathrm{m})$ & 16.5 & $1.80(2 \mathrm{H} ; \mathrm{m})$ & 17.0 \\
\hline 12 & $2.32(2 \mathrm{H} ; \mathrm{m})$ & 34.4 & $2.3(1 \mathrm{H} ; \mathrm{m}) ; 2.5(1 \mathrm{H} ; \mathrm{m})$ & 35.3 \\
\hline 13 & - & 47.1 & - & 47.9 \\
\hline 14 & - & 158.2 & - & 159.7 \\
\hline 15 & $2.24(1 \mathrm{H} ; \mathrm{m})$ & 119.8 & $2.26(1 \mathrm{H} ; \mathrm{m})$ & 120.2 \\
\hline 16 & $1.73(1 \mathrm{H} ; \mathrm{m}) ; 1.91(1 \mathrm{H} ; \mathrm{m})$ & 32.7 & $1.73(1 \mathrm{H} ; \mathrm{m}) ; 1.93(1 \mathrm{H} ; \mathrm{m})$ & 33.6 \\
\hline 17 & $2.79(1 \mathrm{H} ; \mathrm{dd} ; 11.0 ; 18.5)$ & 51.6 & $2.84(1 \mathrm{H} ; \mathrm{dd} ; 7.4 ; 11.3)$ & 52.7 \\
\hline 18 & $1.31(3 \mathrm{H} ; \mathrm{s})$ & 26.8 & $1.35(3 \mathrm{H} ; \mathrm{s})$ & 27.1 \\
\hline 19 & $1.17(3 \mathrm{H} ; \mathrm{s})$ & 31.7 & $1.22(3 \mathrm{H} ; \mathrm{s})$ & 32.1 \\
\hline 20 & & 124.5 & 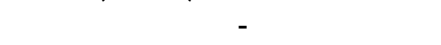 & 125.5 \\
\hline 21 & $7.22(1 \mathrm{H} ; \mathrm{s})$ & 139.8 & $7.40(1 \mathrm{H} ; \mathrm{s})$ & 140.9 \\
\hline 22 & $6.25(1 \mathrm{H} ; \mathrm{d} ; 1.45)$ & 111.0 & $6.40(1 \mathrm{H} ; \mathrm{s})$ & 112.0 \\
\hline 23 & $7.36(1 \mathrm{H} ; \mathrm{d} ; 1.45)$ & 142.7 & $7.50(1 \mathrm{H} ; \mathrm{s})$ & 143.7 \\
\hline 28 & $0.78(3 \mathrm{H} ; \mathrm{s})$ & 20.5 & $1.15(3 \mathrm{H} ; \mathrm{s})$ & 20.7 \\
\hline 29 & $1.23(3 \mathrm{H} ; \mathrm{s})$ & 20.8 & $1.22(3 \mathrm{H} ; \mathrm{s})$ & 20.9 \\
\hline 30 & $1.17(3 \mathrm{H} ; \mathrm{s})$ & 22.7 & $1.22(3 \mathrm{H} ; \mathrm{s})$ & 21.2 \\
\hline $1^{\prime}$ & $1.99(3 \mathrm{H} ; \mathrm{s})$ & 21.0 & $2.00(3 \mathrm{H} ; \mathrm{s})$ & 21.3 \\
\hline $2^{\prime}$ & - & 170.2 & 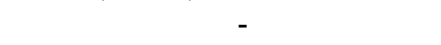 & 170.6 \\
\hline 1" & $2.03(3 \mathrm{H} ; \mathrm{s})$ & 21.4 & $2.00(3 \mathrm{H} ; \mathrm{s})$ & 22.4 \\
\hline $2^{\prime \prime}$ & - & 170.3 & r. & 170.6 \\
\hline
\end{tabular}

* $\left(\mathrm{CDCl}_{3} ;{ }^{1} \mathrm{H}-\mathrm{NMR} 500 \mathrm{MHz} ;{ }^{13} \mathrm{C}-\mathrm{NMR} 125 \mathrm{MHz}\right)$

${ }^{*}\left(\mathrm{CDCl}_{3} ;{ }^{1} \mathrm{H}-\mathrm{NMR} 500 \mathrm{MHz} ;{ }^{13} \mathrm{C}-\mathrm{NMR} 125 \mathrm{MHz}\right)$

\section{CONCLUSIONS}

$6 \alpha$-Acetoxyepoxyazadiradione (1) and dysobinin (2) have been isolated from the seeds of $C$. macrophyllus. The discovery of 1 and 2 supported the occurrence of limonoid in the Chisocheton genus. Compound 1 and 2 were evaluated for their cytotoxic activity against MCF-7 breast cancer cell line. Compound 1 was inactive and compound 2 demonstrated weak cytotoxic activity $(228.15 \mu \mathrm{M})$ against MCF-7 breast cancer cell line. The bioassay data suggested that the carbonyl at $\mathrm{C}-16$ and epoxide at C-14/C-15 in $6 \alpha$-acetoxyepoxyazadiradione (1) decreased the cytotoxic properties.

\section{ACKNOWLEDGMENTS}

We would like to thank the Ministry of Research, Technology and Higher Education for the PTM Grant (N, 2020), Prof. Yoshihito Shiono from Japan Yamagata University, for our research collaboration, Dr. Ahmad Darmawan and Dr. Sofa Fajiah from LIPI Serpong for NMR measurements, Central Laboratory staff for measurement of anticancer activity against MCF-7 cells, The Bogor Botanical Gardens for his plant samples. As well as we would like sincerely thank to Universitas Padjadjaran, Academic Leadership Grant, No. 1959/UN6.3.1/PT.00/2021 by Unang Supratman.

\section{REFERENCES}

Bodduluru, L.N., Kasala E.R., Thota N., Barua C.C., \& Sistla R. (2014). Chemopreventive and Therapeutic Effects of Nimbolide in Cancer: The Underlying Mechanisms. Toxicology in Vitro, $2014 . \quad$ doi: http:// dx.doi.org/10.1016/j.tiv.2014.04.011

Chong, S.L., Awang K., Martin M.T., Mokhtar M.R., Chan G., Litaudon M., Gueritte F., \& Mohamad K. (2012). Malayanines A and $B$, two novel limonoids from Chisocheton erythrocarpus Hiern. Tetrahedron Letters, 53, 5355-5359. doi: $\quad$ http://dx.doi.org/10.1016/j.tetlet. 2012.07.067 
Chong, S.L., Hematpoor, A., Hazni, H., Azirun, M.S., Litaudon, M., Supratman, U., Murata, M., \& Awang, K. (2019). Mosquito larvacidal limonoids from the fruits of Chisocheton erythrocarpus Hiern. Phytochemistry Letters, 30, 69-73.

doi: https://doi.org/10.1016/i.phytol.2018.12.013

Dawkar, V.V., Barage S.H., Barbole R.S., Fatangare A., Grimalt S., Haldar S., Heckel D.G., Gupta V.S., Thulasiram H.V., Svatoš A., \& Giri A.P. (2019). Azadirachtin-A from Azadirachta indica Impacts Multiple Biological Targets in Cotton Bollworm Helicoverpa armigera. ACS Omega, 4, 9531-9541. doi: 10.1021/acsomega.8b03479

Examinati, R.R.I.N., Wulandari, A.P., Harneti, D., \& Poniah, A. (2018). Cytotoxicity of Aromatic Compound from an Endophytic Fungus, Cladosporium SP. EN-S01. International Journal of Current Pharmaceutical Research, 10, 10-12. doi: $\quad$ http://dx.doi.org/10.22159/ijcpr. 2018v10i6.30964

Fang, X., Di, \& Hao. (2011). The Advances in the Limonoid Chemistry of the Meliaceae Family. Current Organic Chemistry, 15, 1363. doi:10.2174/138527211795378254

Gualdani, R., Cavalluzzi M.M., Lentini G., \& Habtemariam S. (2016). The Chemistry and Pharmacology of Citrus Limonoids. Molecules, 21, 1530. doi: 10.3390/molecules21111530

Katja, D.G., Farabi, K., Nurlelasari, Harneti, D., Mayanti, T., Supratman, U., Awang, K., \& Hayashi, H. (2016). Cytototoxic constituents from the bark of Chisocheton cumingianus (Meliaceae). Journal of Asian Natural Product Research, 6, 1-5. doi: http://dx.doi.org/ 10.1080/10286020.2016.1196671

Kumar, V.S., \& Navaratnam V. (2013). Neem (Azadirachta indica): Prehistory to Contemporary Medicinal Uses to Humankind. Asian Pacific Journal of Tropical Biomedicine, 7, 505-514. doi: 10.1016/S22211691 (13)60105-7

Li, H., Peng, \& Zheng. (2016). Metabolic Activation and Toxicities of Furanoterpenoids. Advances in Molecular Toxicology, 10, 55-97. doi: http://dx.doi.org/10.1016/B978-0-12804700-2.00002-7

Nagoor, N.H., Muttiah, N.S., Lim, C.S., In, L.L.A., Mohammad, K., \& Awang, K. (2011). Regulation of Apoptotic Effects by Erythrocarpine $E$, a Cytotoxic Limonoid from Chisocheton erythrocarpus in HSC-4 Human Oral Cancer Cells. Plos One, 6, 1-7. doi: http://10.1371/journal.pone.0023661

Najmuldeen, I.A., Hadi, A.H.A., Mohamad, K., Awang, K., Ketuly, K.A., Mukhtar, M.R., Taha, H., Nordin, M., Litaudon, M., Gueritte, F., Nugroho, A.E., \& Morita, H. (2012).
Chisomicines $D$ and $E$, two new limonoids from Chisocheton ceramicus. Heterocycles, 84, 1265-1270. doi: http://10.3987/COM-11$\mathrm{S}(\mathrm{P}) 31$

Nurlelasari., Katja, D.G., Harneti, D., Wardayo, M.M., Supratman, U., \& Awang, K. (2017). Limonoids from the seeds of Chisocheton macrophyllus. Chemistry of Natural Compounds, 53, 83-87. doi: http://10.1007/s10600-017-1916-4

Pereira, T.B., Silva, L., Amorim, R., Melo, M., Souza, R., Eberlin, M., Lima, E.S., Vasconcellos, M.C., \& Pohlit, A.M. (2014). In vitro and in vivo antimalarial activity of limonoids isolated from the residual seed biomass from Carapa guianensis (andiroba) oil production. Malaria Journal, 13, 317. doi: http://10.1186/1475-2875-13-317

Shi, Y.S., Zhang Y., Li H.T., Wu C.H., El-Seedi H.R., Ye W.K., Wang Z.W., Li C.B., Zhang X.F., \& Kai G.Y. (2020). Limonoids from Citrus: Chemistry, anti-tumor potential, and other Bioactivities. Journal of Functional Foods, 75, 104213. doi: https://doi.org/10.1016/i.jff.2020.104213

Shilpi, J.A., Sahab, S., Chong, S.L., Nahard, L., Sarkerd, S.D., \& Awang, K. (2016). Advances in Chemistry and Bioactivity of the Genus Chisocheton BLUME. Chemistry \& Biodiversity, 13, 483-503. doi: http:// 10.1002/cbdv.201400373

Sophia, J., Kowshik J., Dwivedi A., Bhutia S.K., Manavathi B., Mishra R., \& Nagini S. (2018). Nimbolide, a Neem Limonoid Inhibits Cytoprotective Autophagy to Activate Apoptosis via Modulation of the PI3K/Akt/ GSK-3 $\beta$ Signalling Pathway in Oral Cancer. Cell Death \& Disease, 9, 1087. doi: 10.1038/s41419. 018-1126-4

Supratman, U., Salam S., Naibaho W., Fajar M., Nurlelasari, Katja D.G., Harneti D., Maharani R., Hidayat A.T., Lesmana R., Nafiah M.A., Shiono Y. (2020). New cytotoxic limonoids from the stem bark of Chisocheton pentandrus (Blanco) Merr. Phytochemistry Letters, 35, 6367.doi:

https://doi.org/10.1016/i.phytol.2019.11.002

Supriatno, Nurlelasari., Herlina, T., Harneti, D., Maharani, R., Hidayat, A.T., Mayanti, T., Supratman, U., Azmi, M.N., \& Shiono, Y. (2018). A new limonoid from stem bark of Chisocheton pentandrus (Meliaceae). Natural Product Research, 25, 1-7. doi: https://doi.org/10.1080/14786419.2018.142 8600

Tan, Q., \& Luo, X. (2011). Meliaceous Limonoids: Chemistry and Biological Activities. Chemical Reviews, 111, 7437-7522. doi: https://dx.doi.org/10.1021/cr9004023

Vossen, V.D., \& Umali, B. E. (2002). Plant Resources of South East Asia. Bogor, Indonesia: Prosea Foundation. 
Wang, L., Khoa Phan D.D., Zhang J., Ong P., Thuya W.L., Soo R., Wong A., Yong W.P., Lee S.C., Ho P., Sethi G., \& Goh B.C. (2016). Anticancer Properties of Nimbolide and Pharmacokinetic Considerations to Accelerate Its Development. Oncotarget, 7, 44790-44802. doi: 10.18632/oncotarget.8316
Wong, C.P., Shimada, M., Nagakura, Y., Nugroho, A.E., Hirasawa, Y., Taneda, T., Awang, K., Hadi, A.H.A., Mohamad, K., Shiro, M., \& Morita, H. (2011). Ceramicines E-I, new limonoids from Chisocheton ceramicus. Chemical and Pharmaceutical Bulletin, 59(3), 407-411. 